\title{
Heavy smoking and lung cancer: Are women at higher risk? Result of the ICARE study
}

\author{
A Papadopoulos ${ }^{1,2}$, F Guida ${ }^{1,2}$, K Leffondré ${ }^{3}$, S Cénée ${ }^{1,2}$, D Cyr ${ }^{4}$, A Schmaus ${ }^{1,4}$, L Radoï ${ }^{1,4}$, S Paget-Bailly ${ }^{1,4}$, \\ M Carton ${ }^{4}$, G Menvielle ${ }^{1,4}$, A-S Woronoff ${ }^{5}$, B Tretarre6 ${ }^{6}$ D Luce ${ }^{1,4}$ and I Stücker ${ }^{\star, 1,2}$ \\ ${ }^{1}$ Environmental Epidemiology of Cancer, CESP Centre for Research in Epidemiology and Population Health, U1018, Inserm, 94807 \\ Villejuif, France; ${ }^{2}$ Université Paris Sud 11, UMRS 1018, 94807 Villejuif, France; ${ }^{3}$ Université Bordeaux Segalen, Inserm U897, 33076 \\ Bordeaux, France; ${ }^{4}$ Université de Versailles St-Quentin, UMRS 1018, 94807 Villejuif, France; ${ }^{5}$ Registre des tumeurs du Doubs et du \\ Territoire de Belfort, CHU Saint Jacques, Besançon, France and ${ }^{6}$ Registre des cancers de l'Hérault, Montpellier, France
}

Background: Whether women are more or equally susceptible to the carcinogenic effects of cigarette smoke on the lungs compared with men is a matter of controversy. Using a large French population-based case-control study, we compared the lung cancer risk associated with cigarette smoking by gender.

Methods: The study included 2276 male and 650 female cases and 2780 male and 775 female controls. Lifetime smoking exposure was represented by the comprehensive smoking index (CSI), which combines the duration, intensity and time since cessation of smoking habits. The analysis was conducted among the ever smokers. All of the models were adjusted for age, department (a regional administrative unit), education and occupational exposures.

Results: Overall, we found that the lung cancer risk was similar among men and women. However, we found that women had a two-fold greater risk associated with a one-unit increase in CSI than men of developing either small cell carcinoma (OR $=15.9,95 \%$ confidence interval $(95 \% \mathrm{Cl}) 7.6,33.3$ and $6.6,95 \% \mathrm{Cl} 5.1,8.5$, respectively; $P<0.05)$ or squamous cell carcinoma $(\mathrm{OR}=13.1,95 \% \mathrm{Cl}$ $6.3,27.3$ and $6.1,95 \% \mathrm{Cl}$ 5.0, 7.3, respectively; $P<0.05$ ). The association was similar between men and women for adenocarcinoma.

Conclusion: Our findings suggest that heavy smoking might confer to women a higher risk of lung cancer as compared with men.

Whether women are more or equally susceptible to the carcinogenic effects of cigarette smoke on the lungs compared with men is a matter of controversy. Several case-control studies have indicated that compared with non-smokers, the lung cancer odds ratio associated with a given increase in the amount and duration of cigarette smoking may actually be higher among women than among men (Brownson et al, 1992; Harris et al, 1993; Risch et al, 1993; Zang and Wynder, 1996). However, other casecontrol studies have not shown higher smoking-related risks among females than among males, including a recent large Italianbased case-control study (Schoenberg et al, 1989; Osann et al, 1993; De Matteis et al, 2013). In contrast, the results of four cohort studies published to date have been homogeneous and have found that the incidence of lung cancer among female smokers was about the same as that in male smokers after standardising for the amount smoked (Bach et al, 2003; Bain et al, 2004; Haiman et al, 2006; Freedman et al, 2008). These results are not confirmed by a recent work based on a large UK medical research database which found, using the non-smokers as the reference group, that moderate/heavy smoker women are at higher risk for lung cancer than men, for the same level of smoking (Powell et al, 2013). The debate does not seem to be limited to lung cancer, as exemplified by the recent systematic review showing that women who smoke had a $25 \%$ greater risk of coronary heart disease than male smokers (Huxley and Woodward, 2011).

Most studies have used pack-years of cigarette smoking to investigate the potential modifying effect of gender in smokingrelated lung cancer risk. However, this straightforward index of cumulative exposure makes strong assumptions on the equivalence of the roles of intensity and duration, an assumption that has been 
questioned for example in the context of smoking and lung cancer (Peto, 2012). Other metrics summarising smoking history have been used such as $\ln$ (1+ pack-years/5) (Risch et al, 1993; De Matteis et al, 2013) or ln (cigarettes +1$) \times$ years of smoking (Thurston et al, 2005). However, neither of these other metrics takes into account the time since cessation (TSC), an important parameter of lung cancer risk (Peto et al, 2000; Pirie et al, 2013). The comprehensive smoking index (CSI) is a single aggregate measure of smoking exposure that incorporates intensity, duration and TSC (Leffondre et al, 2006). As the CSI aggregates the three most important components of smoking history into a single variable, it is a practical tool for investigating the interactions between smoking and other factors.

Occupational exposure constitutes the other major determinant of lung cancer and has been regarded as a potential confounder in the comparison of the lung cancer risk related to smoking consumption between genders in some studies (Kreuzer et al, 2000; De Matteis et al, 2013).

The objective of this work was to estimate the overall effect of smoking on lung cancer risk, using the CSI separately for men and women and to investigate whether a modification effect could be observed. We considered all lung cancer together and each main histological type.

\section{MATERIALS AND METHODS}

Study population. The ICARE study, conducted from 2001 to 2007, is a large multicentre population-based case-control study of respiratory cancers. Details of the study design have been described previously (Luce and Stucker, 2011). The present analysis focused on women and men with lung cancer and their population controls. The eligible cases were aged $<76$ years at diagnosis. All histological types were included (ICDO codes C33-34). Among the 3360 eligible cases identified and contacted, 434 refused to participate (response rate $=87 \%$ ). The present analysis included 650 female cases and 2276 male cases.

Population controls with no history of previous respiratory cancer were randomly selected through incidence density sampling from residential telephone directories (Rothman and Grennland, 2008). The controls were frequency matched to the cases by age ( \pm 3 years), gender and department. Additional stratification was used to achieve a distribution by socioeconomic status among the controls comparable to that of the general population in each department. A total of 775 women out of the 1005 female controls eligible that were contacted agreed to participate (77\%), and 2780 out of the 3406 male controls agreed to participate (81\%).

The ICARE study was approved by the Institutional Review Board of the French National Institute of Health and Medical Research (IRB-Inserm, $\mathrm{n}^{\circ}$ 01-036).

Data collection. We used a detailed questionnaire during face-toface interviews. A detailed smoking history was collected for different time periods over the entire smoking lifespan. Periods of non-consumption of at least 1 year were also recorded and were considered when determining the duration of consumption.

Ever smokers were defined as subjects who had smoked at least 100 cigarettes in their lifetime and former smokers were defined as subjects who had stopped smoking for at least 2 years.

Lifetime occupational history was collected and coded according to the International Standard Classification of Occupations (ISCO) and the French Nomenclature of Activities (NAF). In 1982, a list (known as list A) of industries and occupations known to be associated with lung cancer was proposed and is a useful tool when considering occupational exposures. The latest update of this list (Consonni et al, 2010) was applied to our data to adjust for the burden of occupational exposures in this population.
Comprehensive smoking index. Lifetime smoking history was estimated by the CSI proposed for lung cancer (Leffondre et al, 2006), which incorporates duration of smoking (dur), time since cessation (tsc) and smoking intensity (int):

$$
\mathrm{CSI}=\left(1-0.5^{\mathrm{dur} * / \tau}\right) \times\left(0.5^{\mathrm{tsc} * \tau}\right) \times \ln (\mathrm{int}+1),
$$

where $\tau$ is the half-life parameter, $\delta$ is a lag time parameter that modulate the effects of TSC and total duration as follows: $\mathrm{tsc}^{\star}=\max (\mathrm{tsc}-\delta, 0)$ and $\mathrm{dur}^{\star}=\max (\mathrm{dur}+\mathrm{tsc}-\delta, 0)-\mathrm{tsc}^{\star}$.

The lag time parameter $\delta$ accounts for the increase in lung cancer risk that has been observed in the first years after cessation (Leffondre et al, 2002). Tau ( $\tau$ gives information on the form of the dose-response curve between duration (or TSC) and the risk of lung cancer (Leffondre et al, 2006). A shorter $\tau$ mplies a faster levelling-off of the impact of increasing both duration and TSC (see right panels of figures 1 and 2 in Leffondre et al, 2006). To estimate $\tau$ and $\delta$, we estimated a series of logistic regression models, considering men and women together. Each model included the classical adjustment factors (see below) and the CSI as a continuous covariate, with the CSI calculated using a $(\tau, \delta)$ pair selected from a dense two-dimensional grid. We searched a range of 11-50 years in 1-year increments for $\tau$ and a range of $0.1-2.7$ in 0.1 -year increment for $\delta$. These ranges correspond to the limits of the $95 \%$ confidence intervals (CIs) for $\tau$ and $\delta$ found in two other case-control studies on lung cancer (Leffondre et al, 2006). The goodness of fit of the models was compared using Akaike's Information Criterion (AIC). The model that yielded the minimum AIC was identified and the corresponding values of $\tau$ (26 years) and $\delta$ ( 0.7 year) were used in all the analyses. A similar analysis developed in men and women separately indicated that these values of $\tau$ (26 years) and $\delta$ (0.7 years) led to the best goodness of fit.

Other dose metrics of smoking. For comparison purposes, we attempted to replicate our main results using the metrics $\ln (1+$ pack-years/5) (Risch et al, 1993; De Matteis et al, 2013) or ln (intensity +1 ) $\times$ duration (Thurston et al, 2005) instead of the CSI.

Statistical analysis. The analysis was conducted only among ever smokers (i) to avoid the statistical instability due to the very small number of lung cancer cases among never smokers, especially among men and (ii) due to the strong association between lung cancer and gender by histological type among never smokers (i.e., $\mathrm{OR}=7.0(95 \%$ CI (4.6-10.6) and $\mathrm{OR}=2.895 \% \mathrm{CI}(1.3-5.9))$ for adenocarcinoma and squamous cell carcinoma, respectively, for women $v s$ men).

The cutoffs were defined according to the quartiles of the CSI distribution among all the subjects (i.e., cases and controls, male and female). The reference class was the smallest CSI class.

We tested the linearity of the effect of CSI on the logit of lung cancer risk using a smoothing spline function of CSI with 4 degrees of freedom and the linearity was not rejected. We considered therefore the CSI as a continuous variable and estimated the ORs of lung cancer per unit of CSI and formally tested the interactions between gender and CSI by using the likelihood ratio test.

All of the models were adjusted for age, department, education, and occupational exposure (list A).

\section{RESULTS}

The overall socio-demographic characteristics of the cases and controls and the histological subtypes of the lung cancer cases are presented in Table 1. Half of the female cases had adenocarcinomas (53\%), whereas we observed similar proportions of squamous cell and small cell carcinomas (17\% and 15\%, respectively). For male cases, the percentages were $33 \%$ adenocarcinomas, $35 \%$ squamous cell carcinomas and 14\% small cell carcinomas. 
Table 1. Distribution of cases and controls among men and women by socio-demographic characteristics and histological type among cases

\begin{tabular}{|c|c|c|c|c|c|c|c|c|c|c|c|c|c|c|}
\hline & \multicolumn{7}{|c|}{ Male } & \multicolumn{7}{|c|}{ Female } \\
\hline & \multicolumn{2}{|c|}{ Cases } & \multicolumn{2}{|c|}{ Controls } & \multirow[b]{2}{*}{$\mathrm{OR}^{\mathrm{a}}$} & \multirow[b]{2}{*}{$95 \% \mathrm{Cl}$} & \multirow[b]{2}{*}{$\boldsymbol{P}$-value } & \multicolumn{2}{|c|}{ Cases } & \multicolumn{2}{|c|}{ Controls } & \multirow[b]{2}{*}{$\mathrm{OR}^{\mathrm{a}}$} & \multirow[b]{2}{*}{$95 \% \mathrm{Cl}$} & \multirow[b]{2}{*}{$P$-value } \\
\hline & $\mathbf{N}$ & $\%$ & $\mathbf{N}$ & $\%$ & & & & $\mathbf{N}$ & $\%$ & $\mathbf{N}$ & $\%$ & & & \\
\hline Total & 2275 & & 2780 & & & & & 648 & & 775 & & & & \\
\hline \multicolumn{15}{|l|}{ Age at interview, years } \\
\hline $\begin{array}{l}<50 \\
50-60 \\
60-70 \\
\geqslant 70\end{array}$ & $\begin{array}{l}310 \\
773 \\
824 \\
368\end{array}$ & $\begin{array}{l}14 \\
34 \\
36 \\
16\end{array}$ & $\begin{array}{l}663 \\
855 \\
923 \\
339\end{array}$ & $\begin{array}{l}24 \\
31 \\
33 \\
12\end{array}$ & $\begin{array}{l}1.0 \\
1.9 \\
1.9 \\
2.3\end{array}$ & $\begin{array}{c}\text { Ref. } \\
1.6-2.3 \\
1.6-2.2 \\
1.9-2.9\end{array}$ & $P<0.001$ & $\begin{array}{r}160 \\
224 \\
171 \\
93\end{array}$ & $\begin{array}{l}25 \\
35 \\
26 \\
14\end{array}$ & $\begin{array}{l}167 \\
160 \\
263 \\
185\end{array}$ & $\begin{array}{l}21 \\
21 \\
34 \\
24\end{array}$ & $\begin{array}{l}1.0 \\
1.5 \\
0.7 \\
0.6\end{array}$ & $\begin{array}{c}\text { Ref. } \\
1.1-2.1 \\
0.5-1.0 \\
0.4-0.8\end{array}$ & $P<0.001$ \\
\hline \multicolumn{15}{|l|}{ Educational level ${ }^{b}$} \\
\hline $\begin{array}{l}\text { Elementary school or less } \\
\text { Middle school } \\
\text { High school } \\
\text { University }\end{array}$ & $\begin{array}{l}675 \\
869 \\
185 \\
274\end{array}$ & $\begin{array}{r}34 \\
43 \\
9 \\
14\end{array}$ & $\begin{array}{r}521 \\
1081 \\
310 \\
752\end{array}$ & $\begin{array}{l}19 \\
41 \\
12 \\
28\end{array}$ & $\begin{array}{l}1.0 \\
0.6 \\
0.4 \\
0.3\end{array}$ & $\begin{array}{l}\text { Ref. } \\
0.5-0.7 \\
0.4-0.6 \\
0.2-0.3\end{array}$ & $P<0.001$ & $\begin{array}{r}204 \\
208 \\
72 \\
110\end{array}$ & $\begin{array}{l}34 \\
35 \\
12 \\
19\end{array}$ & $\begin{array}{r}242 \\
270 \\
90 \\
149\end{array}$ & $\begin{array}{l}32 \\
36 \\
12 \\
20\end{array}$ & $\begin{array}{l}1.0 \\
0.6 \\
0.7 \\
0.5\end{array}$ & $\begin{array}{l}\text { Ref. } \\
0.5-0.8 \\
0.5-1.0 \\
0.4-0.8\end{array}$ & $P<0.001$ \\
\hline \multicolumn{15}{|c|}{ Occupational exposure (list $A)^{c}$} \\
\hline $\begin{array}{l}\text { Non-exposed } \\
\text { Exposed }\end{array}$ & $\begin{array}{r}1826 \\
438\end{array}$ & $\begin{array}{l}81 \\
19\end{array}$ & $\begin{array}{r}2450 \\
329\end{array}$ & $\begin{array}{l}88 \\
12\end{array}$ & $\begin{array}{l}1.0 \\
1.8\end{array}$ & $\begin{array}{c}\text { Ref. } \\
1.5-2.1\end{array}$ & $P<0.01$ & $\begin{array}{r}623 \\
21\end{array}$ & $\begin{array}{r}97 \\
3\end{array}$ & $\begin{array}{r}767 \\
8\end{array}$ & $\begin{array}{r}99 \\
1\end{array}$ & $\begin{array}{l}1.0 \\
3.0\end{array}$ & $\begin{array}{c}\text { Ref. } \\
1.3-6.9\end{array}$ & $P<0.001$ \\
\hline \multicolumn{15}{|c|}{ Histological types by smoking status } \\
\hline $\begin{array}{l}\text { Never smokers }(\mathrm{CSI}=0) \\
\text { Squamous cell carcinoma } \\
\text { Small cell carcinoma } \\
\text { Adenocarcinoma } \\
\text { Other types } \\
\text { Multiple phenotype }^{d} \\
\text { Ever smokers }(\mathrm{CSI}>0) \\
\text { Squamous cell carcinoma } \\
\text { Small cell carcinoma } \\
\text { Adenocarcinoma } \\
\text { Other types } \\
\text { Multiple phenotype }\end{array}$ & $\begin{array}{r}59 \\
12 \\
2 \\
32 \\
13 \\
- \\
2191 \\
786 \\
330 \\
759 \\
336 \\
20\end{array}$ & $\begin{array}{r}36 \\
15 \\
35 \\
15 \\
3\end{array}$ & $\begin{array}{l}813 \\
- \\
- \\
- \\
- \\
1958 \\
- \\
- \\
- \\
-\end{array}$ & & & & & $\begin{array}{r}188 \\
23 \\
6 \\
133 \\
27 \\
1 \\
457 \\
82 \\
89 \\
221 \\
70 \\
5\end{array}$ & $\begin{array}{r}12 \\
3 \\
70 \\
14 \\
\\
18 \\
19 \\
48 \\
15\end{array}$ & $\begin{array}{l}513 \\
- \\
- \\
- \\
- \\
260 \\
- \\
- \\
- \\
- \\
-\end{array}$ & & & & \\
\hline
\end{tabular}

The range of the values of the CSI was 0-2.71 among controls and 0-3.08 among cases ever smokers. Mean pack-years, intensity, duration and TSC across CSI classes in men and women controls are presented in Table 2. As can be seen, women classified in the first two classes of CSI had a smoking history lighter than men, mainly because of a lower average intensity. We found that the effect of smoking by CSI class on lung cancer was quite similar for men and women. The OR associated with a one-unit increase in CSI was also close and not significantly different $(P=0.5)$.

Table 3 presents the OR for the three histological types of lung cancer associated with the CSI. For squamous cell lung cancer, the OR was two-fold greater in women than in men $(P=0.04)$. In contrast, for adenocarcinomas the OR was higher in men than in women but the difference was not significant. Finally, the analysis for small cell lung cancer showed an OR two-fold greater in women than in men $(P<0.05)$.

Table 4 presents the ORs of lung cancer associated with the CSI (model 1$)$, with $\ln (1+\mathrm{PY} / 5)($ model 2$)$ or $\ln ($ intensity +1$) \times$ duration (model 3) in our population of men and women ever smokers, each metric of smoking consumption being considered as a continuous variable. Each model included an interaction term between the metric of smoking consumption and sex. Models 2 and 3 additionally included the TSC, plus an interaction term with sex. When all lung cancers were pooled together, the fits to data of models 1 and 3 were equal and both better than model 2. The ORs of lung cancer were systematically higher for men smokers than for women smokers although not significant. Model 1 in squamous and small cells lung cancer yielded a better AIC than models 2 or 3 . The ORs were higher in women than in men whatever the metric used, but interaction with sex was significant only in model 1. On the other hand for adenocarcinoma the fits to data of models 1 and 3 were similar and better than model 2 . The OR for adenocarcinoma was stronger in men smokers than in women smokers.

\section{DISCUSSION}

In this work, we have shown that when comparing lung cancer risks associated with smoking between genders, results vary according to histological type. 
Table 2. Means of pack-years, intensity, duration, time since cessation among controls, by categories of CSI and estimated odds ratio for the association between lung cancer and CSI among the ever smokers

\begin{tabular}{|c|c|c|c|c|c|c|c|c|}
\hline \multirow[b]{2}{*}{ CSI } & \multirow[b]{2}{*}{ Pack-years $^{a}$} & \multirow[b]{2}{*}{$\begin{array}{l}\text { Intensity } \\
\text { (cig/day) }\end{array}$} & \multirow[b]{2}{*}{$\begin{array}{c}\text { Duration }^{a} \\
\text { (years) }\end{array}$} & \multirow[b]{2}{*}{$\begin{array}{c}\mathrm{TSC}^{\mathrm{a}} \\
\text { (years) }\end{array}$} & \multirow[b]{2}{*}{ Cases (\%) } & \multirow[b]{2}{*}{ Controls (\%) } & \multicolumn{2}{|c|}{ Ever smokers } \\
\hline & & & & & & & $\mathrm{OR}^{\mathrm{b}}$ & $95 \% \mathrm{Cl}$ \\
\hline Male & & & & & $\mathbf{N}=2191$ & $N=1958$ & & \\
\hline $\begin{array}{l}\leqslant 0.73 \\
0.73-1.40 \\
1.40-1.90 \\
>1.90 \\
\text { Dose-response }^{c}\end{array}$ & \begin{tabular}{r|}
8.4 \\
22.8 \\
34.2 \\
58.1 \\
\end{tabular} & $\begin{array}{l}11.3 \\
16.3 \\
18.8 \\
25.0\end{array}$ & $\begin{array}{l}13.3 \\
27.2 \\
35.1 \\
43.7\end{array}$ & $\begin{array}{r}27.6 \\
14.1 \\
7.6 \\
5.0\end{array}$ & $\begin{array}{l}202(9) \\
447(20) \\
643(29) \\
899(41)\end{array}$ & $\begin{array}{l}859(44) \\
582(30) \\
347(18) \\
170(9)\end{array}$ & $\begin{array}{r}1.0 \\
3.3 \\
8.0 \\
20.3 \\
5.5\end{array}$ & $\begin{array}{c}\text { Ref. } \\
2.6-4.1 \\
6.4-10.1 \\
15.8-26.0 \\
4.9-6.3\end{array}$ \\
\hline Female & & & & & $N=457$ & $\mathbf{N}=\mathbf{2 6 0}$ & & \\
\hline $\begin{array}{l}\leqslant 0.73 \\
0.73-1.40 \\
1.40-1.90 \\
>1.90 \\
\text { Dose-response }^{c}\end{array}$ & \begin{tabular}{r|}
3.7 \\
16.7 \\
31.0 \\
54.9 \\
\end{tabular} & \begin{tabular}{r|}
6.9 \\
12.2 \\
18.8 \\
28.7
\end{tabular} & $\begin{array}{l}11.5 \\
27.0 \\
33.8 \\
41.9\end{array}$ & $\begin{array}{r}25.0 \\
12.0 \\
5.8 \\
4.2\end{array}$ & $\begin{array}{r}48(10) \\
94(21) \\
183(40) \\
132(29)\end{array}$ & $\begin{array}{c}116(45) \\
84(32) \\
45(17) \\
15(6)\end{array}$ & $\begin{array}{r}1.0 \\
2.7 \\
9.1 \\
20.0 \\
4.9\end{array}$ & $\begin{array}{c}\text { Ref. } \\
1.6-4.5 \\
5.4-15.2 \\
10.0-40.0 \\
3.6-6.7\end{array}$ \\
\hline \multicolumn{7}{|c|}{$P$-value for interaction gender $\times \mathrm{CSI}$} & \multicolumn{2}{|c|}{$P=0.5$} \\
\hline \multicolumn{9}{|c|}{ 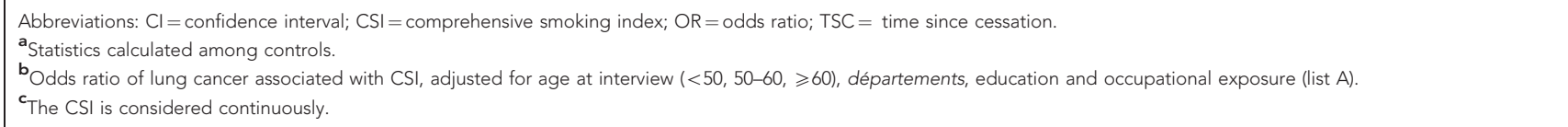 } \\
\hline
\end{tabular}

Table 3. Estimated odds ratio for the association between CSI and each histological type of lung cancer

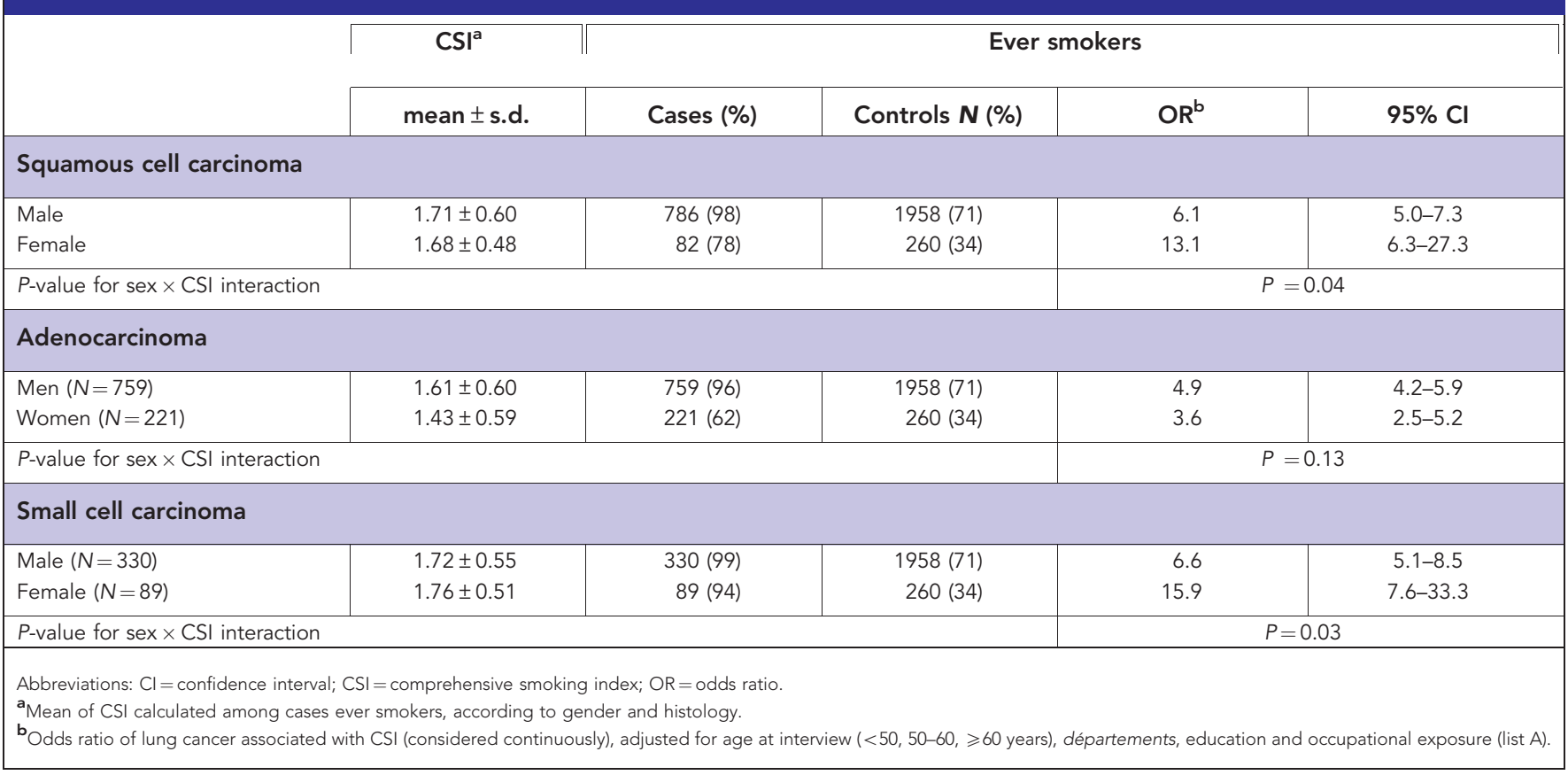

Synthesizing the various dimensions of smoking information to better capture the smoking history represents a challenge, and the most common approach has been to use pack-years. However, this index does not include the delay since smoking cessation, which is also an important component of lung cancer risk (Peto et al, 2000). Cohort studies have compared the incidence rate of lung cancer between gender stratified by smoking categories including a category for ex-smokers, even though this complicates the global assessment of the gender/smoking interaction (Freedman et al, 2008).

We estimated the two parameters ( $\delta$ and $\tau$ ) of the CSI considering men and women together to avoid introducing variability between genders in the shape of the dose-response curves that are determined by $\tau$. Furthermore, we obtained similar values for $\delta$ and $\tau$ when we checked that these estimates also corresponded to the best goodness of fit when considering men and women separately. We treated the CSI as a continuous variable in the logistic models and restricted the population to the ever smokers as previous studies had done (Brownson et al, 1992; Harris et al, 1993; Zang and Wynder, 1996; De Matteis et al, 2012, 2013).

Several case-control studies (Schoenberg et al, 1989; Osann et al, 1993; Kreuzer et al, 2000; De Matteis et al, 2013) and 


\begin{tabular}{|c|c|c|c|c|c|c|c|c|c|c|c|c|c|c|c|c|}
\hline \multirow[b]{2}{*}{$\begin{array}{l}\text { Smoking } \\
\text { metric } \\
\left.(\text { model })^{\mathrm{a}}\right)\end{array}$} & \multicolumn{3}{|c|}{ All lung cancer } & \multicolumn{5}{|c|}{ Squamous cell carcinoma } & \multicolumn{4}{|c|}{ Small cell carcinoma } & \multicolumn{4}{|c|}{ Adenocarcinoma } \\
\hline & $\mathrm{AlC}^{\mathrm{b}}$ & $\begin{array}{c}\text { Males } \\
\text { OR }^{c} \\
95 \% \mathrm{Cl}\end{array}$ & $\begin{array}{c}\text { Females } \\
\text { OR }^{c} \\
95 \% \mathrm{Cl}\end{array}$ & $P^{d}$ & $\mathrm{AlC}^{\mathrm{b}}$ & $\begin{array}{c}\text { Males } \\
\text { OR }^{\mathrm{c}} \\
95 \% \mathrm{Cl}\end{array}$ & $\begin{array}{c}\text { Females } \\
\text { OR }^{\mathrm{c}} \\
95 \% \mathrm{Cl}\end{array}$ & $P^{d}$ & $A I C^{b}$ & $\begin{array}{c}\text { Males } \\
\text { OR }^{\mathrm{c}} \\
95 \% \mathrm{Cl}\end{array}$ & $\begin{array}{c}\text { Females } \\
\mathrm{OR}^{\mathrm{c}} \\
95 \% \mathrm{Cl}\end{array}$ & $P^{d}$ & $\mathrm{AIC}^{\mathrm{b}}$ & $\begin{array}{c}\text { Males } \\
\text { OR }^{c} \\
95 \% \mathrm{Cl}\end{array}$ & $\begin{array}{c}\text { Females } \\
\text { OR }^{\mathrm{c}} \\
95 \% \mathrm{Cl}\end{array}$ & $P^{d}$ \\
\hline Model 1 & 4578 & $5.5(4.9-6.3)$ & $4.9(3.6-6.7)$ & 0.40 & 2337 & $6.1(5.0-7.3)$ & $13.1(6.3-27.3)$ & 0.04 & 1514 & $6.6(5.1-8.5)$ & $15.9(7.6-33.3)$ & 0.03 & 2791 & $4.9(4.2-5.9)$ & $3.6(2.5-5.2)$ & 0.10 \\
\hline Model 2 & 4587 & $4.0(3.4-4.7)$ & $3.1(2.2-4.3)$ & 0.10 & 2348 & $4.1(3.3-5.2)$ & $5.1(2.7-9.7)$ & 0.50 & 1537 & $4.0(3.0-5.3)$ & $5.6(3.0-10.5)$ & 0.32 & 2802 & $3.8(3.1-4.7)$ & $2.6(1.8-3.9)$ & 0.09 \\
\hline Model 3 & 4580 & $1.3(1.3-1.4)$ & $1.3(1.2-1.3)$ & 0.10 & 2350 & $1.3(1.3-1.4)$ & $1.3(1.2-1.5)$ & 0.80 & 1538 & $1.29(1.2-1.4)$ & $1.4(1.2-1.5)$ & 0.20 & 2790 & $1.32(1.3-1.4)$ & $1.2(1.1-1.3)$ & 0.07 \\
\hline \multicolumn{17}{|c|}{ 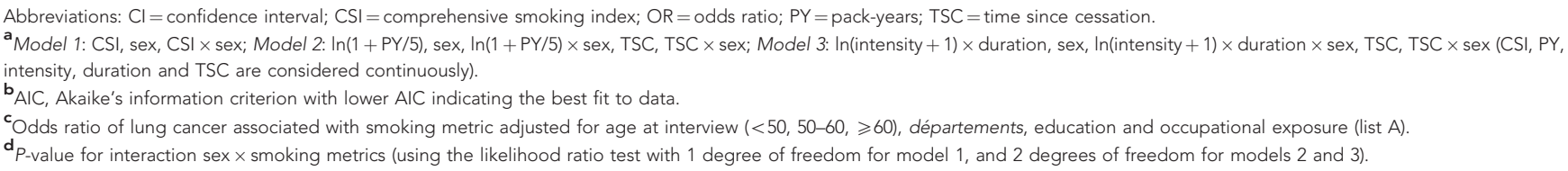 } \\
\hline
\end{tabular}

prospective studies (Bach et al, 2003; Bain et al, 2004; Haiman et al, 2006; Freedman et al, 2008) have found no overall differences in risk between genders. Although we also found no overall difference in risks between genders, the risk of squamous and small cell lung cancer was higher in women as compared with that in men. The high proportion of adenocarcinoma (38\%) explained why we did not observe any overall difference. Squamous and small cells lung cancer are the histological types the most strongly related to smoking (Khuder and Mutgi, 2001). In our population, women with squamous cells and especially small cells lung cancer were heavy smokers. Their average CSI was close to that of male cases for squamous cells (1.71 vs 1.68 in women and men, respectively) and even higher for small cells (1.76 vs 1.72 in women and men, respectively). The same mean estimated on the whole lung cancer group is lower in women than in men (1.55 and 1.66, respectively). It is noteworthy that the higher associations among women than among men were also found for these two histological types in the previous studies (Brownson et al, 1992; Harris et al, 1993; Risch et al, 1993; Zang and Wynder, 1996), a result confirmed by the meta-analysis from Khuder and Mutgi (2001).

It could therefore be likely that heavy smoking carries a higher risk for women than for men. Lung cancer in men and women differs in many aspects, survival, histology, genetic alterations in tumours, which suggests that carcinogenesis might be different in men and women (Novello and Baldini, 2006; O'keeffe and Patel, 2008, Gasperino, 2010; Kiyohara and Ohno, 2010). A recent work based on a UK medical research database, comprising 12121 incident cases of lung cancer and 48216 controls, also found a higher risk of lung cancer in women than in men, that increased with the level of smoking assessed by the highest intensity ever smoked (Powell et al, 2013). Various reasons could support a deleterious effect of smoking higher in women than in men including possibly differential enzymatic activity of genes involve in tobacco smoke metabolism (Mollerup et al, 2006). The role of hormonal and reproductive factors on female lung carcinogenesis is currently heavily debated, and a possible interaction between smoking and hormonal factors should also be considered. Such an interaction between smoking and estrogens replacement therapy has been observed once, but to our knowledge never reproduced (Taioli and Wynder, 1994). In addition, EGFR and KRAS, two driver mutations of lung carcinogenesis, are now well known for their particular distribution with gender and smoking history (Cooper et al, 2013). A large recent study specific from adenocarcinoma showed a specificity of the type of K-RAS mutations with sex and also, interestingly, that women with this specific mutation had a significantly lower pack-year consumption as compared with men (Dogan et al, 2012). A similar result had been previously found with P53, a tumor suppressor gene frequently mutated in lung cancer (Kure et al, 1996; Toyooka et al, 2003). Altogether, these findings may also support a possible higher susceptibility of tobacco carcinogenesis in women.

Finally, this higher susceptibility might not be specific of lung cancer, since a large review of cigarette smoking and coronary heart disease also shows that women present a risk ratio relative to men of 1.25 (1.12-1.39) (Huxley and Woodward, 2011).

A comparison of our findings with those of similar studies is not easy because we are the first to have compared the effects of smoking between genders using the CSI to estimate the lifelong smoking history. The most recent publication on this topic, using a different metric (i.e., $\ln (1+\mathrm{PY} / 5)$ to evaluate the lifelong smoking history, did not find any difference in risk between genders (De Matteis et al, 2013). Their population and ours are similar in many respects: they are two European populations, with similar gender distribution, displaying a similar proportion of highly educated men and women (high school or more). The proportion of never smokers among cases in men as in women is very close, the mean pack-years of cigarette smoking among women ever smokers were almost identical to our numbers (i.e., 33 and 15 in women cases and controls, respectively) and the average delay since smoking cessation almost identical in cases and controls, among men as well as among women. All these comparisons demonstrate a level of smoking intoxication similar in the two populations. However, although the De Matteis et al study found slightly higher odds ratios in women than in men for squamous and small cells lung cancer associated with smoking, they did not find any statistical interactions. However, their number of women with squamous and small cells lung cancer (38 and 35, respectively) was smaller than in this study. To compare our results with already published studies, including De Matteis et al, we examined the smoking-gender interaction with a logistic regression that included the cumulative exposure index estimated with $\ln (1+\mathrm{PY} / 5)$, in addition to an interaction term between sex and TSC to make models 2 (i.e., $\ln (1+\mathrm{PY} / 5))$ and 3 (i.e., $\ln$ (intensity +1$) \times$ duration) more comparable to the CSI. Our results also became non-significant, although the ORs associated with smoking were still higher in women than in men. These last results demonstrate that the manner in which smoking history is synthetized is clearly critical. Because the range of the values of each metric is clearly different, it is not possible to compare the values of the ORs between the three models. Time since cessation modulates the risk of lung cancer (Pirie et al, 2013). Comprehensive smoking index integrates this important parameter in the assessment of lifelong smoking history 
and it is interesting to note that the best AIC is achieved with the model that includes CSI while models 2 and 3 treat TSC as a confounder (including an interaction term with sex).

Among the criticism also often levelled at studies indicating higher risks for women is that baseline risks are likely to be different in never-smoking women than in never-smoking men (i.e., less work-related exposure to lung carcinogens for women), although this was not observed in Freedman's cohort (Freedman et al, 2008). To consider this possible confounder, we adjusted our results for occupational exposure through the typical variable List A that we already used in a previous work focused specifically on occupational exposures (Guida et al, 2011). We also made an additional adjustment for the type of tobacco smoked (light tobacco, dark tobacco or mixed). This did not alter any result (data not shown).

Recall bias in case-control design is always a matter of concern. However, in the topic we are interested in, the problem is less in the validity of lifelong smoking history reported than in a potential differential recall bias between men and women. Indeed, if women tend to underreport their true consumption more than men or to a lesser extent, the consequence would tend to overestimate the risk in women as compared with men. This hypothesis should also be considered although this bias is not specific to the case-control design. Cohort studies also rely on self-questionnaire or face-toface interviews at baseline and during follow-up. It could be interesting to examine this hypothesis in the near future, using both cotinine biomarker and self-report to assess smoking and then comparing results in men and women.

Our study also has several strengths: we included incident cases, population controls were randomly selected in the same départements as cases through incidence density sampling, the participation rate was over $80 \%$ in cases and controls and subjects were interviewed face to face by trained interviewers using a structured questionnaire.

In summary, to resolve the question of whether women have a greater susceptibility to smoking-related lung cancer than men, it is important to consider the results both for all lung cancer cases and also by histological type. Incorporating time since smoking cessation in the smoking metric seems to better summarize the lifelong history. Further studies using the CSI instead of pack-years of cigarette smoking to compare the smoking effects on lung cancer in men and women are needed to move forward in this debate. The results we obtained for small cells and squamous cells lung cancer might also suggest that women heavy smokers are more susceptible to tobacco smoking. This hypothesis should be considered like any others, especially as the aetiology of women lung cancer is known only by the knowledge obtained in men.

\section{ACKNOWLEDGEMENTS}

This work was supported by several agencies: the Foundation de France, the French National Research Agency (ANR), the Foundation for Medical Research (FRM), the French Institute for Public Health Surveillance (Institut de veille sanitaire, InVS), the Health and Sport Department (Direction Générale de la Santé et des Sports), Foundation for the Research on Cancer (Fondation ARC pour la Recherche contre le Cancer, ARC), the National Institute for Cancer (INCa) and the Ministry of work, solidarity and civil service (Direction Générale du Travail). The authors thank American Journal Experts for their editorial assistance.

\section{CONFLICT OF INTEREST}

The authors declare no conflict of interest.

\section{REFERENCES}

Bach PB, Kattan MW, Thornquist MD, Kris MG, Tate RC, Barnett MJ, Hsieh LJ, Begg CB (2003) Variations in lung cancer risk among smokers. J Natl Cancer Inst 95: 470-478.

Bain C, Feskanich D, Speizer FE, Thun M, Hertzmark E, Rosner BA, Colditz GA (2004) Lung cancer rates in men and women with comparable histories of smoking. J Natl Cancer Inst 96: 826-834.

Brownson RC, Chang JC, Davis JR (1992) Gender and histologic type variations in smoking-related risk of lung cancer. Epidemiology 3: 61-64.

Consonni D, De Matteis S, Lubin JH, Wacholder S, Tucker M, Pesatori AC, Caporaso NE, Bertazzi PA, Landi MT (2010) Lung cancer and occupation in a population-based case-control study. Am J Epidemiol 171(3): 323-333.

Cooper WA, Lam DC, O'toole SA, Minna JD (2013) Molecular biology of lung cancer. J Thorac Dis 5: S479-S490.

De Matteis S, Consonni D, Lubin JH, Tucker M, Peters S, Vermeulen R, Kromhout H, Bertazzi PA, Caporaso NE, Pesatori AC, Wacholder S, Landi MT (2012) Impact of occupational carcinogens on lung cancer risk in a general population. Int J Epidemiol 41: 711-721.

De Matteis S, Consonni D, Pesatori AC, Bergen AW, Bertazzi PA, Caporaso NE, Lubin JH, Wacholder S, Landi MT (2013) Are women who smoke at higher risk for lung cancer than men who smoke? Am J Epidemiol 177(7): 601-612.

Dogan S, Shen R, Ang DC, Johnson ML, D’angelo SP, Paik PK, Brzostowski EB, Riely GJ, Kris MG, Zakowski MF, Ladanyi M (2012) Molecular epidemiology of EGFR and KRAS mutations in 3,026 lung adenocarcinomas: higher susceptibility of women to smoking-related KRAS-mutant cancers. Clin Cancer Res 18: 6169-6177.

Freedman ND, Leitzmann MF, Hollenbeck AR, Schatzkin A, Abnet CC (2008) Cigarette smoking and subsequent risk of lung cancer in men and women: analysis of a prospective cohort study. Lancet Oncol 9: 649-656.

Gasperino J (2010) Gender is a risk factor for lung cancer. Med Hypotheses 76(3): 328-331.

Guida F, Papadopoulos A, Menvielle G, Matrat M, Fevotte J, Cenee S, Cyr D, Schmaus A, Carton M, Paget-Bailly S, Radoï L, Tarnaud C, Bara S,

Trétarre B, Luce D, Stücker I (2011) Risk of lung cancer and occupational history: results of a French population-based case-control study, the ICARE study. J Occup Environ Med 53: 1068-1077.

Haiman CA, Stram DO, Wilkens LR, Pike MC, Kolonel LN, Henderson BE, Le Marchand L (2006) Ethnic and racial differences in the smoking-related risk of lung cancer. $N$ Engl J Med 354: 333-342.

Harris RE, Zang EA, Anderson JI, Wynder EL (1993) Race and sex differences in lung cancer risk associated with cigarette smoking. Int J Epidemiol 22: 592-599.

Huxley RR, Woodward M (2011) Cigarette smoking as a risk factor for coronary heart disease in women compared with men: a systematic review and meta-analysis of prospective cohort studies. Lancet 378: 1297-1305.

Khuder SA, Mutgi AB (2001) Effect of smoking cessation on major histologic types of lung cancer. Chest 120: 1577-1583.

Kiyohara C, Ohno Y (2010) Sex differences in lung cancer susceptibility: a review. Gend Med 7: 381-401.

Kreuzer M, Boffetta P, Whitley E, Ahrens W, Gaborieau V, Heinrich J, Jöckel KH, Kreienbrock L, Mallone S, Merletti F, Roesch F, Zambon P, Simonato L (2000) Gender differences in lung cancer risk by smoking: a multicentre case-control study in Germany and Italy. Br J Cancer 82: 227-233.

Kure EH, Ryberg D, Hewer A, Phillips DH, Skaug V, Baera R, Haugen A (1996) p53 mutations in lung tumours: relationship to gender and lung DNA adduct levels. Carcinogenesis 17: 2201-2205.

Leffondre K, Abrahamowicz M, Siemiatycki J, Rachet B (2002) Modeling smoking history: a comparison of different approaches. Am J Epidemiol 156: 813-823.

Leffondre K, Abrahamowicz M, Xiao Y, Siemiatycki J (2006) Modelling smoking history using a comprehensive smoking index: application to lung cancer. Stat Med 25: 4132-4146.

Luce D, Stucker I (2011) Investigation of occupational and environmental causes of respiratory cancers (ICARE): a multicenter, population-based case-control study in France. BMC Public Health 11: 928.

Mollerup S, Berge G, Baera R, Skaug V, Hewer A, Phillips DH, Stangeland L, Haugen A (2006) Sex differences in risk of lung cancer: expression of genes in the PAH bioactivation pathway in relation to smoking and bulky DNA adducts. Int J Cancer 119: 741-744. 
Novello S, Baldini E (2006) Women and lung cancer. Ann Oncol 17(Suppl 2): ii79-ii82.

O'keeffe P, Patel J (2008) Women and lung cancer. Semin Oncol Nurs 24: 3-8.

Osann KE, Anton-Culver H, Kurosaki T, Taylor T (1993) Sex differences in lung-cancer risk associated with cigarette smoking. Int J Cancer 54: $44-48$.

Peto J (2012) That the effects of smoking should be measured in pack-years: misconceptions 4. Br J cancer 406-407.

Peto R, Darby S, Deo H, Silcocks P, Whitley E, Doll R (2000) Smoking, smoking cessation, and lung cancer in the UK since 1950: combination of national statistics with two case-control studies. BMJ 321: 323-329.

Pirie K, Peto R, Reeves GK, Green J, Beral V (2013) The 21st century hazards of smoking and benefits of stopping: a prospective study of one million women in the UK. Lancet 381: 133-141.

Powell HA, Iyen-Omofoman B, Hubbard RB, Baldwin DR, Tata LJ (2013) The association between smoking quantity and lung cancer in men and women. Chest 143: 123-129.

Risch HA, Howe GR, Jain M, Burch JD, Holowaty EJ, Miller AB (1993) Are female smokers at higher risk for lung cancer than male smokers? A case-control analysis by histologic type. Am J Epidemiol 138: 281-293.
Rothman K, Grennland S (2008) Modern Epidemiology. Lippincott Williams and Wilkins: Philadelphia, PA.

Schoenberg JB, Wilcox HB, Mason TJ, Bill J, Stemhagen A (1989) Variation in smoking-related lung cancer risk among New Jersey women. Am J Epidemiol 130: 688-695.

Taioli E, Wynder EL (1994) Re: Endocrine factors and adenocarcinoma of the lung in women. J Natl Cancer Inst 86: 869-870.

Thurston SW, Liu G, Miller DP, Christiani DC (2005) Modeling lung cancer risk in case-control studies using a new dose metric of smoking. Cancer Epidemiol Biomarkers Prev 14: 2296-2302.

Toyooka S, Tsuda T, Gazdar AF (2003) The TP53 gene, tobacco exposure, and lung cancer. Hum Mutat 21: 229-239.

Zang EA, Wynder EL (1996) Differences in lung cancer risk between men and women: examination of the evidence. J Natl Cancer Inst 88: 183-192.

This work is published under the standard license to publish agreement. After 12 months the work will become freely available and the license terms will switch to a Creative Commons AttributionNonCommercial-Share Alike 3.0 Unported License. 